\title{
Obrana „antropocentrismu“
}

\author{
A Defence of "Anthropocentrism"
}

Vlastimil Hála

\begin{abstract}
This article focuses on the novum, contributed by environmental ethics to the interpretation of ethical problems in general. Environmental ethics has transcended hitherto ethical concepts, which are based on the only interpersonal schemes, by opening the area of nature and "non-human" beings as a relevant topic for ethics and axiology. However, the impulse of environmental ethics brings other philosophical problems, especially in the field of value interpretation. The focus on the value interpretation of natural objects leads, namely, in some kinds of environmental approaches (e.g. biocentrism) to onesided value-objectivism; values are interpreted as "inherent" or "intrinsic" and the relevance of the human valuative position is overshadowed. In contrast, the author pleads for a "cultivated anthropocentrism" and stresses the relevance of the human position as a "centre" for the possibility of evaluation, including that of the status of nature and "non-human beings". The author does not accept the simplistic identification of "anthropocentrism" with the position which holds that nature exists only for human purposes and exploitation.
\end{abstract}

KEY WORDS ethics, environment, anthropocentrism, values

\section{Hledání viníků}

Člověk je svým způsobem v kosmu něčím zcela zvláštním; jiné svým způsobem zcela zvláštní živé bytosti jsou slunečnice, želvy... kočky...

(Meyer-Abich 2001: 256)

Ve svém př́spěvku nebudu vstupovat do subtilnějších diskusí mezi jednotlivými proudy speciálně ekologicky zaměřených koncepcí; v tomto ohledu mohu odkázat především na níže citovanou práci M. Skýbové. Pokusil jsem se podívat na ekologickou problematiku poněkud „Zvnějšku“", z hlediska obecnější filosofické problematiky.

Až do doby poměrně nedávné - zhruba do 70 . let dvacátého století - se etika týkala téměř výlučně mezilidských vztahů (př́ípadně $\mathrm{s}$ přesahem $\mathrm{k}$ náboženství). Pokud se hovořilo o „konečnosti“, šlo o konečnost lidské existence. Teprve vědomí konečnosti, respektive neobnovitelnosti př́rodních zdrojů, bylo praktickým impulsem, který přiměl představitele různých oborů - a též filosofie - $\mathrm{k}$ reflexi tohoto vztahu jako naléhavého etického problému.

Sociálni studia. Katedra sociologie FSS MU, 1/2013. S. 63-73. ISSN 1214-813X. 
Viník neblahého stavu vztahu člověka $\mathrm{k}$ př́írodě projevujícího se jako ekologická krize byl hledán většinou v renesančním, respektive novověkém obratu v chápání „místa člověka

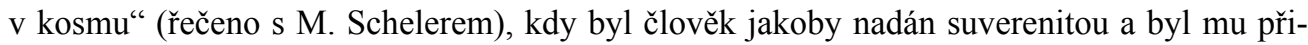
znán mj. i neomezený majetnický vztah $\mathrm{k}$ prrírodě, jež zde byla od té doby jen jakoby „k dispozici“. Oblíbenými terči ekologické kritiky, zejména z konzervativních pozic, byli Hobbes a Descartes (Trpák 1991). Někteří autoři hodnotící prríčinu tohoto stavu sáhli ještě hlouběji a obvinili z takového sebepojetí člověka křest’anskou tradici, př́ípadně určitou její interpretaci. Člověk podle toho byl ne teprve v novověku, ale už v kořenech evropské civilizace a kultury biblickým pojetím vyzdvižen jako „obraz Boži““ na piedestal výlučnosti vuči přírodě a tvorům, kteří ji spoluvytvářejí. At’ už byl viník identifikován jakkoli (u nás se druhá interpretace př́iliš neujala, nejspíš z obavy intelektuálů projevit kritický vztah vůči ,„̌idovsko-křest’anské tradici“), shoda byla a je $\mathrm{v}$ tom, že na počátku scestného vývoje stála nesprávná koncepce vztahu člověka k př́rodě. Ovšem i ti z nás, kdo se domnívají, že Hobbes či Descartes spíše reflektovali určitý pohyb lidských dějin, myšlení apod., než že by se dějiny řídily neblahým impulsem jejich myšlení, se shodují na tom, že postupně vznikla nová situace i pro promýšlení etických otázek, včetně otázky hodnot.

\section{Hodnoty v novém světle}

$\mathrm{V}$ ekologických př́stupech $\mathrm{k}$ axiologické problematice nepůjde o „nietzscheovské“ přehodnocení „,š̌ech“ hodnot; spíše než o přehodnocení půjde o rozšířní jejich „akčního rádia“. Obrat k ekologické problematice ve smyslu vtažení, zahrnutí prírody a „mimo-lidských“ tvorů, kteří prírodu spolu s námi vytvářejí, do souřadnic etiky má i obecnější předpoklady: je součástí emancipačně-demokratizačního trendu vtahování, začleňování i dosud neprivilegovaných a diskriminovaných bytostí do univerzálních standardů uznání a práv. Primárně se jednalo o lidská společenství: ženy, námezdně pracující, lidí žijících menšinovými životními styly apod. V tomto ohledu přináší ekologická filosofie a zvlášt' etika podstatné rozšriření: kontinuitu uvnitř základního zlomu.

Konkrétní podoba promýšlení oněch problémů je ovšem různá; v českém prostředí měly asi největší rezonanci myšlenky inspirativní osobnosti českého ekologického myšlení Josefa Vavrouška, někdejšího ministra životního prostředí, který formuloval své vidění ekologické problematiky jako „hledání lidských hodnot slučitelných s trvale udržitelným způsobem života“, což zahrnovalo vztah lidí k př́rodě, individua ke společnosti, vztah lidí k toku času a smyslu dějin, ke smyslu vlastního života, svobodě a odpovědnosti, k úrovni našeho poznání, $\mathrm{k}$ vlastnímu životu, $\mathrm{k}$ budoucím generacím, odlišným názorům a jiným civilizacím a konečně k věcem společným (Plos a Vavroušek 1994: 46-51).

Ekologická filosofie nedala ovšem pouze obecný impuls etice tím, že vyzdvihla př́rodu jako partnera vztahu a jako hodnotu, kterou byl dříve jen druhý člověk nebo společnost, ale též obnovila, respektive postavila do nového světla, některá tradiční filosofická témata, především otázku hodnot v užším smyslu. Povaha „,hodnot“ byla ve filosofii intenzívně diskutována zvláště v druhé půli 19. století a v první půli století dvacátého. Dělo se tak na velmi abstraktní rovině a souvislosti byly až na výjimky mezilidské; jeden z představitelů hodnotově orientované etiky N. Hartmann chápal hodnoty na způsob platónských „ideji““. 
Ekologická filosofie sdílí s tradiční problematikou hodnot některé dřívější spory, jež vyvstávají tehdy, máme-li zodpovědět konkrétnější otázky po povaze hodnot, jako je otázka, zda hodnota je vlastností bytí, respektive objektů, k nimž je hodnocení vztaženo, nebo zda je vytvářena hodnotícím aktem. Zároveň ale tím, že byla inspirována bezprostředním prožitkem prírody a vědomím krizovosti jejího stavu, vnesla zvláště ve svých bio-, respektive fyziocentrických formách do jejich pojetí něco, co v jiné souvislosti (totiž v rámci kritiky zavádění fiktivních objektů v teorii A. Meinonga jako zdůraznění našeho silného smyslu pro realitu, jemuž se libovolné konstruování takových objektů príčí) nazval B. Russell „robustním realismem“ (Russell 1919: 169-170) nebo ještě dříve mladý K. Marx v první tezi o Feuerbachovi „nazíravým materialismem“ (Marx a Engels 1958: 17-19). Hodnota je v těchto pojetích totiž něčím, co existuje, je dáno naprosto nezávisle na člověku, jeho perspektivě, na aktivitě „subjektu“, lidských cílech apod.

Člověk jako „subjekt“ vychází v takových pojetích jako pouhý registrátor něčeho, co existuje mimo něj a nezávisle na něm, co je „o sobě“ a objektivně, př́padně co je vlastností bytí a co, pokud se na přírodu dívá prriměřeným způsobem, pokud tedy odhlédá právě od vlastních cílů a záměrů, pouze jako hodnotu identifikuje. Takové chápání je zaměřeno proti „hypertrofii subjektu“ $v$ moderní filosofii, kultu člověka a panskému vztahu k př́rodě, zapomíná ale nezř́ídka na svébytné a jedinečné postavení člověka v prrírodě, na to, v jakém smyslu je „centrem“, jaký význam má lidská perspektiva, hovoří-li se o hodnotách.

Pokud totiž jde o vtažení prírody do souřadnic toho, co je pro člověka životně důležité a co má pro něj bezprostředně etický význam, je mezi lidmi obecně se hlásícími $\mathrm{k}$ základním ekologickým myšlenkám vcelku jasno. Rozdíly nastupují tam, kde je třeba formulovat určitější pojetí vztahu člověka $\mathrm{k}$ př́rodě. $\mathrm{V}$ tomto ohledu se vyhranily schematicky řečeno dva základní směry, na jedné straně bio- (případně fyzio- či eko-) centrismus, na druhé antropocentrismus. Rozdíl mezi nimi spočívá zhruba řečeno $\mathrm{v}$ důrazu na ten či onen pól vztahu člověk-príroda.

Podle pojetí významného německého ekologického filosofa K. M. Meyera-Abicha, představitele „fyziocentrismu“, který je možno chápat jako rozšiřený biocentrismus, je antropocentrikem ten, kdo si myslí, že všechno, co není člověk, je zde jen „k dispozici“. Člověk se k tomu vztahuje tak, že to může „mít“. Meyer-Abich využívá slavného heideggerovského motivu „zapomenutosti bytí“, který ovšem transformuje v ekologicky realistickém smyslu $\mathrm{v}$,Zapomenutost př́rody.“ Pojem antropocentrismu je pro něj převážně obecným titulem pro nesprávný vztah ke světu, vyvozující starost o prírodu z lidského zájmu, tedy z perspektivy ve svém sebepojetí privilegované lidské bytosti (Meyer-Abich 1997: 17, 77-82, 110-111).

Ovšem všichni biocentrikové nejsou vučci antropocentrismu tak odmítaví, například M. Skýbová uznává závažnost argumentů zejména „slabého“ antropocentrismu (Skýbová 2011: 37-39, 76). Slabý antropocentrismus charakterizuje R. Kolářský v návaznosti na B. G. Nortona (Norton 1984: 131-148) jako stanovisko opírající se o nahlédnutí, že je třeba rozlišovat racionální a neracionální lidské zájmy, přičemž ty druhé mohou a mají být předmětem kritické reflexe (Kolářský 2011: 94). 
SOCIÁLNÍ STUDIA 1/2013

\section{Člověk jako centrum}

V ekologických filosofíích nemá tedy antropocentrismus př́liš dobrou pověst; je v něm spatřován dědic dosavadního, prírodu přehlížejícího myšlení. Klíčovou otázkou ale je, jakým zpuosobem je člověk chápán jako „centrum“: zda je centrem veškerého významu tak, že všechno je vztaženo jen $\mathrm{k}$ němu, jeho životu a cílům, zda jedině on si připisuje hodnotu, respektive hodnotu výlučnou: $\mathrm{v}$ takovém př́ípadě jde samozřejmě o hrubé pojetí a na takový typ antropocentrismu se opravdu vztahují ony negativní charakteristiky, kterými častují filosofický antropocentrismus jako východisko ekologické filosofie a etiky jeho bio-, fyzio-, eko- apod. centrističtí kritici.

Jinak ale tomu je, chápeme-li, jako i autor tohoto zamyšlení, antropocentrismus ve smyslu akcentu na jedinečný způsob lidského bytí, kde člověk je centrem perspektivy, z níž se jedině smysluplně ukazuje něco jako hodnota, a to třeba i vlastní hodnota př́rody a „mimo-lidských“ tvorů; v tomto ohledu je člověk „osmyslujícím“ středem. Možná by také mohly být diskusím mezi ekologicky orientovanými filosofy užitečné podněty hodnotově orientované etiky, která měla pro základní rys mezilidských etických vztahů krásné pojmenování: hodnotová odpovéd' (Hildebrand 1973: 43). Ukazuje člověka v situaci, jež jakoby apeluje na jeho hodnotové cítění i mravní rozhodnutí.

Hodnotová etika se pohybovala ve fenomenologické tradici, pro niž hodnotová odpověd' nebyla pouze receptivním či pasivním postojem, nýbrž intencionálním výkonem, aktivitou. Nezabývala se speciálně ekologickou tematikou, ta zde vystupuje jen implicitně a okrajově, ale bylo by ji možno právě v této souvislosti aktualizovat. To, co platí pro vztahy mezi lidmi, platí totiž v neztenčené míře i pro vztah lidí $\mathrm{k}$ prírodě: i tuto „mimo-lidskou“ prírodu chápeme totiž vždy již „,hodnotově“, jako něco, co nám není lhostejné, k čemu nemáme neutrální vztah. Člověk má na světě - v naší souvislosti na př́rodě - vždy již zájem, který je primárně existenciálního rázu. Ve fenomenologické tradici se také zdůrazňuje vztah mezi (hodnotovou) odpovědí a odpovědností. Bylo to vyzdviženo i v souvislosti s významem odpovědnosti u Jana Patočky, kde byl víckrát zdůrazněn význam odpovědnosti jako odpovědi na apel světa (Horák a Zumr 1992). I odpovědnost za prŕrodu lze vyvodit $\mathrm{z}$ tohoto kontextu.

Jestliže byl kritizován subjekt-objektový vztah vnesený do filosofie novověkem, pak lze jeho absolutnost oddělení subjektu a objektu relativizovat i z „druhé strany“, než jak to činí biocentrikové kritizující hypertrofii subjektu, totiž poukazem na ono „,ždy již“, na axiologicky-zájmový vztah člověka ke světu, na - byt’ původně implicitní - tematizaci světa jako celku, jako absolutního přesahu ve smyslu něčeho, do čehož člověk náleží, k čemuž přináleží.

\section{„Rozšîrená komunita“: Partnerství pro mír?}

Kritikové antropocentrismu často říkají, že člověk se nestoudně a pansky agresivně povýšil nad celek př́rody (případně Stvoření, a takto nad Boha). Ale výjimečnost není možno hned zkratkovitě ztotožňovat s nadřazeností či pansky pyšným vztahem. K. M. Meyer-Abich předestřel - právě ve snaze překonat zmíněnou lidskou nadřazenost - myšlenku „rozšǐřeného komunitarismu“ (Meyer-Abich 1997: 368, 373, 387). Míní jím společenství lidí a „mimo-lidských bytostí“, přičemž pro jejich vztah volí výraz „spolubytí“. Lidský a mimo-lidský svět tak tvoří sdilené společenství (,Mitwelt“), v němž „mimo-lidský“ svět není chápán jen jako 
životní prostředí („Umwelt“), jež je nám vnějším okolím (Meyer-Abich 1990: 11). Hlavní Meyer-Abichovou tezí je, že nemáme privilegované postavení, nýbrž přináležíme $\mathrm{k}$ př́rodě sice svébytně, ale nejinak než jiné bytosti, třeba jako kočka „kočičím způsobem“, strom „stromově“ apod. (Meyer-Abich 1997: 82). Duchaplně to vyjádřil oním uvedeným tvrzením, jež posloužilo jako motto tohoto textu.

Kritici panského a manipulativního vztahu člověka $\mathrm{k}$ prírodě proto ve jménu odmítnutí privilegovanosti člověka horují pro to, abychom se začali vǐči př́rodě chovat nikoli pansky, nýbrž partnersky, abychom s ní žili „v míru“. Tuto myšlenku opět formuloval MeyerAbich a převzal např́klad mad’arský filosof $Z$. Endreffy; u nás je blízká R. Kolářskému a M. Skýbové (Endreffy 1995; Skýbová 2011, 2012). Požadavek „míru s př́rodou“ má nepochybně chvályhodný záměr, ale je i paradoxní, nebot' je vlastně postulátem ,protipř́rodním“: vždyt' př́roda sama je nejen kooperace, kterou považuje M. Skýbová za převažujíć́ v souvislostech biosféry (nedokážu posoudit, jsem spíš skeptický), ale i neustávající boj; právě takovým, tzn. „mírovým“ vztahem se člověk z př́rody vyčleňuje par excellence, neméně, byt' jinak, než ovládá-li ji technickými prostředky za účelem manipulace a využívání ku svému prospěchu; príroda neni , mírem" a naše „mírové" chování vióči ní není „přirodni".

\section{Dobro a prospívání jako kritérium?}

Zde samožrejmě vyvstává otázka: Co by tedy mělo být kritériem našeho přiměřeného vztahu $\mathrm{k}$ přirodě? Někteří ekologičtí filosofové, jako u nás stoupenkyně biocentrismu M. Skýbová (jež ale zvažuje i kritické námitky vůči takovému pojetí), prosazují myšlenku, že je to uznání „vlastní hodnoty“ přrirody, přičemž opírají pojem vlastní hodnoty o kritérium teleologického sledováni vlastního dobra, prospívání (Skýbová 2011: 103-110). Dobro je zde něčím, co je objektivně v zájmu toho kterého organismu, respektive bytosti. Autorka se odvolává na amerického ekologického filosofa P. W. Taylora, který se domnívá, že právě realizace tohoto dobra je to, co má být podporováno a chráněno. Morální ohled proto zasluhuje vše živé, co má své dobro. Kritérium prospivání, dobra organismu nebo vlastní hodnoty umožňuje zařadit do okruhu našich morálních ohledů nejen nižší živočichy, ale také rostliny.

Kritérium prospívání, „dobra“ jednotlivých bytostí ovšem pro naše rozhodování rovněž nedostačuje: tato „dobra“ se realizují nejen v harmonii, ale i v konkurenci, protikladu a boji; takříkajíc se „tlučou“. Podporovat prospívání jednotlivých bytostí nebo ekosystémů je pak úkolem zase jedině pro člověka, který, at' chce či nechce, je v situaci, kdy tato dobra mimo-lidských individuí či ekosystémů musí zvažovat a rozhodovat se, kterým dá přednost; např́iklad zda dobru a prospívání kưrovce, anebo stromů. Zvažujeme-li ekologicky naléhavé otázky jakkoli, vždy se vrátíme zas $k$ sobě samým.

\section{Život jako střed}

Jakkoli jsou tedy myšlenky koncepcí snažících se překonat antropocentrismus inspirující a jistě ušlechtilé, vyvolávají základní pochybnost: Je člověk opravdu ve světě pouze stejně svébytným způsobem jako jiné bytosti? Není to právě jedinečná perspektiva lidské existence, jíž se otevírá „,svět“, respektive konkrétněji príroda jako celek tím, co umožňuje ono 
„hodnotovée“ chápání a „odpovídáni“"? Takto oceňujeme na základě svého vnímání př́rody jako celku ty př́rodní útvary - jako je třeba prales -, které pokládáme za významné pro naše pojetí př́rody, at' už jako něco, co je hodnotné pro náš život ve světě jako faktor rovnováhy, jako neobnovitelný „zdroj“, ale i jako existenciálně-estetický faktor, impuls meditace, prožitku spolunáležitosti apod.; Meyer-Abich to krásně vyjadřuje jako „spoluvnímání srdcem“ (Meyer-Abich 1990: 18). Jistě by zde bylo možno prripomenout i Kantovu „krásu“ a „vznešenost" nebo - když ještě více odbočím - třeba i básnickou kompozici Vznešenost př́rody českého básníka M. Z. Poláka (Polák 2003).

Spolu s tím se svébytnost lidské pozice projevuje i v tom, že nevnímáme tvory, kteři spolu s námi př́rodu spoluvytvářejí, nivelizovaně, nýbrž jako určitou škálu: škálu spontánně orientovanou $\mathrm{k}$ nám, jako $\mathrm{k}$ jedinečným bytostem. Takto se nám jeví jako „důležitějšš‘ ti živočichové, kteří jsou nám bližší vývojově, respektive ke kterým máme důvěrnější vztah: jako jsou lidoopi nebo domácí „mazličci“. Neznamená to ovšem, že by člověk chápal přírodu tak, že se její význam vyčerpává vztahem $\mathrm{k}$ němu, ale tato dimenze je $\mathrm{v}$ našich vztazích $\mathrm{k}$ prírodě vždy nějak prítomna.

Předpokladem toho, že se ke světu vztahujeme hodnotově angažovaně a zainteresovaně, je tedy svébytný zpơsob našeho bytí. Německý filosof H. Plessner to bliže charakterizoval jako „excentrickou pozicionalitu“ (Plessner 1975). Obdobně vystihl jeho krajan H.-E. Hengstenberg základní rozdíl mezi zpưsobem bytí člověka a zvířete tak, že zvíre žije „ze středu“ (aus Mitte), zatímco člověk ,jako střed“ (als Mitte), s čímž podle tohoto autora souvisí přesvědčení, že jen člověk má vědomí sebe sama, tedy „sebevědomi““ (Hengstenberg 1966). Na základě novějších výzkumů bychom dnes nechápali tento rozdíl absolutně, ale i tak nám právě jen tato svébytnost umožňuje vnímat př́rodu jako celek, jako zahrnující přesah, jako „svět"“. I díky tomuto přesahu můžeme rozprostř́i náš zájem o prrírodu, svět jako celek i za hranice naší konkrétní časové představivosti. Právě jen výlučně v lidské perspektivě odhalující něco jako celkovost se může objevit i smysl pro ono jiné než lidské; lidská perspektiva je totiž něčím transcendujícím „pouze“ lidské, jen z této perspektivy se může objevit něco jako hodnota, napríiklad stromu či zviřete, ne $\mathrm{z}$, jejich“ omezeného a jen zprostředkovaně př́stupného „zorného úhlu“; ne z identifikace, ale z distance.

Biocentricky orientovaní autoři mají tendenci minimalizovat rozdíl mezi člověkem a zvířaty; oporou je jim napríklad fakt, že šimpanz je člověku co do genetického vybavení bližší než gorile: máme s ním společných přes $98 \%$ genů. Kvalitativní rozdíl mezi člověkem a zvířaty se ovšem nevyčerpává biologickými předpoklady; způsobem svého bytí, který by bylo možno „staromódně“ nazvat bytím duchovním, jak o tom asi naposledy mluvil N. Hartmann (Hartmann 1962). Jím se člověk relativně „distancuje“ od bezprostředního začlenění do přírody, ale uvnitř této sounáležitosti. Je to tato principiální a kvalitativní svébytnost, jež mu zaručuje jedinečné postavení v komunitě bytostí, jež jsou součástí př́rody, což se projevuje mj. i jako schopnost vytvářet „druhou prírodu“: kulturu a civilizaci v kontrastu $\mathrm{k}$ "př́ŕodě“ v základním smyslu; v tomto ohledu se člověk jistě liší od šimpanze víc než šimpanz od gorily (Skýbová 2011: 54-55). Myšlenku „rozšířeného komunitarismu“ tedy není třeba odmítat, za neudržitelné považuji pouze její nivelizované pojetí, jež nechce vidět jedinečnost lidského bytí ve světě. 
Jestliže zastávám hledisko antropocentrismu $\mathrm{v}$ uvedeném smyslu, neznamená to, že bych nepovažoval za inspirativní podněty přicházející z protilehlého břehu. Napríílad MeyerAbichova myšlenka „rozšiřeného komunitarismu“, pokud ji nechápeme v rovnostářském smyslu a uvědomujeme si, že právě zde vyvstává zřetelně nezastupitelnost a jedinečnost lidského způsobu bytí, může být přeformulována $\mathrm{v}$ požadavek citlivého, kultivovaného „správcovského“, respektive „pastýřského“ vztahu k prrírodě. Takový vztah člověka vůči př́ŕodě není něčím závislým na náboženských predpokladech: vyplývá z našeho mista ve světě, z povahy člověka jako bytosti nadané onou ,excentrickou“ pozicionalitou, schopnou tematizovat svět jako celek, hodnotově jej vnímat a také mít hierarchizovaný vztah k různým typům bytostí, jež ho spoluvytvářejí. Součástí tohoto výjimečného způsobu bytí člověka ve světě je i schopnost tvořit kulturu, ale i manipulativně-ovladatelský vztah k přírodě i ,jejím“ tvorům, který člověk může a měl by omezovat, ale ze kterého se nemůže libovolně stáhnout.

\section{„Poslední člověk“ a mez antropocentrismu}

I antropocentrickému hledisku ovšem některé otázky „komplikuji““ život. Nejvíce mě donutil k přemýšlení myšlenkový experiment „posledního člověka“, který přednesl kdysi na konferenci ve Varně ekologický filosof R. Routley (Routley 1975) a který uvedla v rámci své argumentace pro biocentrismus Marie Skýbová (Skýbová 2008: 14, 2012: 321-330). Je zde simulována situace poslední lidské bytosti, jež brzy zemře a napadne ji zničit z rozmaru poslední zbývající sekvoji. Sekvoje tedy už nebude moci mít jakýkoli užitečný význam pro člověka, který nebude existovat, ale ani jinou hodnotu, třeba estetickou nebo existenciální, protože zde nebude nikdo, kdo by nějakým způsobem sekvoji, prŕípadně jiný krásný př́rodní útvar vnímal a ocenil. Je možné zde stále ještě podržet „,antropocentrickou“ argumentaci v uvedeném smyslu „kultivovaného antropocentrismu“, respektive antroporelacionismu? (Kemper 2001).

Jestliže jsem dospěl ke stanovisku, že o hodnotě má smysl mluvit pouze ve vztahu, nikoli ji chápat jako něco principiálně nezávislého na lidském hodnocení, ani jako něco lidským hodnocením teprve ustavovaného, virtuální situace posledního člověka přece jen ukazuje na mez i takto chápaného antropocentrismu; sekvoje, stejně jako ostatní rostliny, zvírata i prŕroda jako celek v takovém prípadě zůstanou bez - třeba jen potenciálního - vnímatele, hodnotitele ap. V takové situaci už člověk takříkajíc „přestává mluvit“, přestává hodnotově odpovídat, být partnerem. Zde je i ten nejkultivovanější antropocentrismus, antropocentrismus jako vztažení, jako metodické východisko atp., vyřazen.

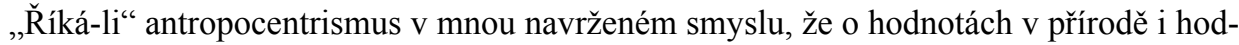
notě př́rody má smysl hovořit pouze z lidské perspektivy a lidským jazykem, že je to součást lidské artikulace, jíž „hodnotově odpovídáme“ na naši situaci ve světě, neznamená to, že se tím status prírody vyčerpává, že je tím řečeno vše. Vztažením hodnotového chápání přírody k lidské perspektivě neříkám zároveň, že neexistují nebo že jsou nicotné perspektivy jiné, že jedině relevantní je ona perspektiva lidská - ostatně dynamická a rozšiřující se vědeckým poznáním, citlivostí vůči problémům, jež si uvědomujeme teprve $\mathrm{v}$ určitých dějinných souvislostech ap. Říkám-li, že naše lidská perspektiva nám neumožňuje „myslet jako hora“, neříkám tím zároveň, že hora má smysl jen v naší lidské perspektivě. Říkám-li, že pozitivní výpovědi 
můžeme pronášet o „mimolidské“ přírodě jen z naší perspektivy, že můžeme o světě, o př́irodě mluvit jen jak je „pro nás“, což platí i tehdy, přiřkneme-li jí „vlastní hodnotu“, neříkám tím zároveň, že svět je „zde“ jen pro nás a kvưli nám, že pozitivně víme, že má smysl jen v kontextu, $v$ němž o něm můžeme smysluplně mluvit. Můžeme jen předpokládat, že svět není hodnotově neutrální, když nás vybízí k hodnotovému odpovídání. Snad by to bylo možno vyjádřit i tak, že „osmyslováni““ světa člověkem je spíše než autonomní tvorbou aktualizací smyslu a hodnotových dimenzí, které (nejspiš) jsou - alespoň jako potence - ve světě př́tomny. Ponechávám zde stranou klíčovou otázku, totiž nemá-li prríroda nějaký pozitivní účel, jehož jsme pouze, byt' třeba privilegovanou, součástí. $\mathrm{K}$ tomu bychom museli zaujmout jiné, třeba „božské“, absolutní apod. stanovisko, což je nám ale odepřeno. Nepřijímám-li takové hledisko pozitivně, nemohu je alespoň pozitivně vyloučit, protože nemohu argumentovat pro opak.

Teprve takový antropocentrismus, který by vedl, respektive mohl vést k postulátu zničení sekvoje, by byl ten panský, nadřazený, považující prrírodu jen za objekt manipulace. Vrátíme-li se k virtuální situaci „posledního člověka“, lze říci, že jestliže člověk vnímal prírodu „vždy již“" hodnotově, proč by měl vůči tomu, co mu přinášelo takové obohacení, existenciální prožitek absolutního přsahu, zaujímat nepřátelské stanovisko? Nechci-li užít „obnošeného“ (krásný výraz J. Wericha) výrazu „pokora“, vyjádřil bych svůj pocit jako vděčnost př́rodě, která se jakoby rozprostírá za životy nás lidí a jejich souvislosti. Naproti tomu antropocentrismus kultivovaný je si vědom svých mezí a usiluje o zahrnutí nejrůznějších mimolidských perspektiv do perspektivy lidské jako jejich obohacení; přestože je může zohlednit vždy jen „přes filtr" perspektivy vlastní, neskýtá ničitelskému záměru argumentační základnu.

\section{Závěrem}

Domnívám se, že speciální analýzy ekologické problematiky by měly spočívat na nějakém obecnějším filosofickém základě, $\mathrm{k}$ němuž se autor výslovně přihlásí. Těchto základů může být více, $\mathrm{u}$ nás např́klad prosazuje $\mathrm{v}$ tomto ohledu svébytnou koncepci evoluční ontologie J. Šmajse (Šmajs a Krob 2003).

Ani spor o status hodnot $\mathrm{v}$ prrírodě, hodnoty jednotlivých tvorů, organismů nebo celých biotických celků ap. není podle mého názoru možné smysluplně diskutovat bez akceptování nějaké obecnější filosofické koncepce. Př́stupy pohybující se - například - ve směru předznamenaném Kantem či Husserlem, kladoucí hlavní důraz na aktivitu „subjektu“, „mysli“, „Ega“ ap., sotva mohou bez dalšího hovořit o objektivním, na člověka zcela nezávislém statusu hodnot, protože tuto problematiku vždy vidí vztaženou ke svébytné perspektivě lidského osvojování světa (jehož existence je $\mathrm{v}$ krajně subjektivistickém př́stupu dokonce kladena do „závorek“ či zpochybňována).

Naopak filosofie chápající, at’ už materiální, ale třeba i ideální „svět hodnot“ jako něco existujícího mimo člověka a nezávisle na něm - např́ílad „nazíravé““ typy materialismu kritizované „,mladým“ Marxem, ale i axiologický objektivismus N. Hartmanna či fundamentální ontologie pozdního Heideggera s jejím samopohybem „Bytí“ - by úlohu člověka vnímaly především jako registrátora a odhalovatele něčeho o sobě jsoucího, svébytného. Bez širšího filosofického fundamentu může docházet $\mathrm{k}$ tomu, $\mathrm{k}$ čemu skutečně dochází: ke zmatení „diskursů“. 
Co se týče naší problematiky, snad by bylo možno se inspirovat volně Kantem, jeho myšlenkou vztahu ,jevu“ a „,věci o sobě“; ve svých pozitivních výpovědích o prírodě jsme vázáni na to, jak se nám jeví, ale to, co nás „afikuje“, není vyčerpáno podmínkami naší perspektivy, je to „věc o sobě““. Podobně naše hodnotové, zprvu implicitní, v průběhu života stále více explicitní vnímání světa (jež není totožné s racionálním poznáním, i když s ním souvisí), nám umožňuje naši lidskou perspektivu variovat, nikoli z ní vystoupit; je rozezníváno něčím mimo tuto perspektivu, co ono hodnotové vnímání „afikuje“: světem, bytím, v našem kontextu konkrétně prírodou.

Český ekologický filosof R. Kolářský se dotkl našeho problému, když konstatoval sbližování přístupů antropocentrického a biocentrického (Kolářský 2011: 92-110). Oba se totiž ukazují být spíše osvětleními žádoucího vztahu člověka $\mathrm{k}$ př́rodě ze dvou různých stran: biocentrismus rozšiřuje oblast toho, co zahrnujeme do souřadnic našich morálních vztahů, antropocentrismus zdůrazňuje pozici, z niž se něco takového nejen ukazuje, ale i vůbec může ukázat. Antropocentrismus považuji za schůdnější, protože stř́zlivěji pojatý společenský program - př́íkladem může být Šmajsův důraz na zavádění „biofilních“ prvků do našeho dosud převážně protipř́rodního kulturního vývoje (Šmajs 1995, 2012: 313-316), ale biocentrismus může (a musí) být jeho korektivem jako spiše individuální hodnotová orientace, která jde proti tomu, co lze na základě dosavadní zkušenosti od člověka očekávat. Ostatně i v otázce filosofických př́istupů k ekologické problematice platí Kollárova slova: „cesty mohou býti rozličné, jenom vůli mějme všichni rovnou“" (Kollár 2011: 24).

\section{Literatura}

ATTFIELD, Robin. Environmental Ethics. An Overview for the Twenty-First Century. 1. vyd. Cambridge: Polity Press, 2003. ISBN 0745627382.

EHRENFELS, Christian von. Werttheorie. Philosophische Schriften. Bd 1, vydal R. von Fabian. München: Philosophia Verlag, 1982. ISBN 3-88405-033-8.

ENDREFFY, Zoltán. Frieden mit den Menschen - Frieden mit der Natur. In Unum omnes in Christo. Miscelanea, vol. 1. Separatum: Panonhalma, 1995. ISSN 1218-1374.

HÁLA, Vlastimil. Klaus Michael Meyer-Abich: Filosofie rozšířeného komunitarismu. In HÁLA, Vlastimil, Dagmar SMREKOVÁ, Zuzana PALOVIČOVÁ a Rudolf KOLÁŘSKÝ. Etika a jej tradícia. Bratislava: Fox \& Col, 2006, s. 34-57. ISBN 9788096951420.

HÁLA, Vlastimil. Robert Spaemann: Konzervativní reakce na (post-) modernu. In HÁLA, Vlastimil, Dagmar SMREKOVÁ, Zuzana PALOVIČOVÁ a Rudolf KOLÁŘSKÝ. Etika a jej tradicia. Bratislava: Fox \& Col, 2006, s. 9-33. ISBN 9788096951420.

HARTMANN, Nicolai. Ästhethik. Berlin: Walter de Gruyter, 1966. ISBN 3110001462, 9783110001464.

HARTMANN, Nicolai. Das Problem des geistigen Seins. 3. vyd. Berlin: Walter de Gruyter, 1962. ISBN 3110048094.

HENGSTENBERG, Hans-Eduard. Philosophische Anthropologie. 3. vyd. Stuttgart: W. Kohlhammer Verlag, 1966.

HILDEBRAND, Dietrich von. Ethik, 2. Aufl., Bd. II der Gesammelten Werke. Stuttgart: Kohlhammer Verlag 1973. ISBN 3170011596, 9783170011595.

HORÁK, Petr a Josef ZUMR (eds.). La Responsabilité - Responsibility: Entretiens de Prague, Institut international de philosophie. Praha: Filosofický ústav ČSAV, 1992. IBSN 80-7007-036-6. 
HRUBEC, Marek. Od zneuznáni ke spravedlnosti. Kritická teorie globální společnosti a politiky. Praha: Filosofia, 2011. ISBN 978-80-7007-362-9.

KANT, Immanuel. Kritika čistého rozumu. Přeložil I. Chvatík, J. Loužil, J. Chotaš. Praha: OIKOYMENH, 2001. ISBN 80-7298-035-1.

KANT, Immanuel. Kritika soudnosti, přel. V. Špalek a W. Hansel. Praha: Odeon 1975.

KEMPER, Anne. Unverfügbare Natur. Ästhetik, Anthropologie und Ethik des Umweltschutzes. Frankfurt am Main: Campus Verlag 2001. ISBN 9783593367620.

KOLLÁR, Jan. Slávy dcera [online] [cit. 20. 5. 2013]. V MKP 1. vyd. Praha: Městská knihovna v Praze, 2011. Dostupné z: http://web2.mlp.cz/koweb/00/03/37/06/49/slavy_dcera.html.

KOLÁŘSKÝ, Rudolf. Filosofický význam současné ekologické krize. Praha: Filosofia, 2011. ISBN 978-80-7007-361-2.

MARX, Karel a Bedřich ENGELS. Spisy. Sv. 3, Praha: SNPL, 1958.

MEYER-ABICH, Karl Michael. Wege zum Frieden mit der Natur. Praktische Naturphilosophie für die Umweltpolitik. Wien: C. Hanser Verlag, 1984. ISBN 3-446-14131-6.

MEYER-ABICH, Karl Michael. Aufstand für die Natur. Von der Umwelt zur Mitwelt. München: C. Hanser Verlag, 1990. ISBN 3-446-14889-2.

MEYER-ABICH, Karl Michael. Praktische Naturphilosophie. Erinnerung an einen vergessenen Traum. München: H.C. Beck Verlag, 1997. ISBN 978-3-406-41990-4.

MEYER-ABICH, Karl Michael. Für wen hat die Natur einen Eigenwert? Die Abhängigkeit der ökologischen Ethik vom Menschenbild. In BIASI, Luca di a kol. (eds.). Nachhaltigkeit in der Ökologie. München, C.H. Beck Verlag 2001, s. 243-262. ISBN 3406475612.

NORTON, Bryan G. Environmental Ethics and Weak Anthropocentrism. Environmental Ethics, 1984, roč. 6, č. 2, s. 131-148, DOI: 10.5840/enviroethics19846233.

OTT, Konrad. Ökologie und Ethik. Ein Versuch praktischer Philosophie. Tübingen: Attempto Verlag 1993. ISBN 3893081623.

PLESSNER, Helmuth. Die Stufen des Organischen und der Mensch: Einleitung in die philosophische Anthropologie. 3. vyd. Berlin: W. de Gruyter, 1975. ISBN 3110845342, 9783110845341.

POLÁK, Milota Zdirad. Vznešenost př́rody. Praha: Ad Fontes, 2003. ISBN 80-902927-4-7.

ROLSTON, Holmes III. Philosophy Gone Wild. Essays in Environmental Ethics. New York: Buffalo Prometheus Books, 1986. ISBN 0879753293.

ROUTLEY, Richard Sylvan. Is There a Need for a New, an Environmental Ethic? Proceedings of the XVth World Congress of Philosophy. September 17-22, 1973, Varna, Bulgaria: Sofia Press 1975, s. $205-210$.

RUSSELL, Bertrand. Introduction to Mathematical Philosophy. London: G. Allen \& Unwin, Ltd., 1919, s. $169-170$.

SCHELER, Max. Der Formalismus in der Ethik und die materiale Wertethik. Neuer Versuch der Grundlegung eines ethischen Personalismus. 5. vyd. Bern: A. Francke, 1966.

SEEL, Martin. Eine Ästhetik der Natur. Frankfurt a. M.: Suhrkamp Verlag, 1991. ISBN 3518288318.

SIEP, Ludwig. Konkrete Ethik. Frankfurt a. M.: Suhrkamp Verlag, 2004. ISBN 3518288318.

SKÝBOVÁ, Marie. Etika a př́roda. Červený Kostelec: P. Mervart, 2011. ISBN 978-80-87378-80-9.

SKÝBOVÁ, Marie. Kam sahá hranice našich morálních ohledů. Filosofický časopis, 60, 2012, č. 2, s. 321-330, ISSN 0015-1831.

SKÝBOVÁ, Marie. Vlastni hodnota přirody. Disertační práce. Olomouc: Univerzita Palackého, 2008.

SMREKOVÁ Dagmar, Zuzana PALOVIČOVÁ, Vlastimil HÁLA a Rudolf KOLÁŘSKÝ. Podoby etiky. Bratislava: Filozofický ústav SAV, 2009. ISBN 978-80-969770-9-3.

SPAEMANN, Robert. Grenzen. Zur ethischen Dimension des Handelns. 2. vyd. Stuttgart: Clett-Cotta, 2002. ISBN 3-608-91027-1. 
Vlastimil Hála: Obrana „antropocentrismu“

SPAEMANN, Robert. Philosophische Essays. Stuttgart: Ph. Reclam jun., 1994. ISBN 3150079616 , 9783150079614.

ŠMAJS, Josef. Deklarace závislosti. Filosofický časopis, 2012, roč. 60, č. 2, s. 313-316, ISSN 0015-1831.

ŠMAJS, Josef a Josef KROB. Evolučni ontologie. Brno: Masarykova univerzita, 2003. ISBN 8021030380.

ŠMAJS, Josef. Filosofie-Obrat k Zemi. Evolučně ontologická reflexe přirody, kultury, techniky a lidského poznání. Praha: Academia, 2008. ISBN 978-80-200-1639-3.

ŠMAJS, Josef. Ohrožená kultura. Od evoluční ontologie k ekologické politice. Brno: „Zvláštní vydáni““, 1995. ISBN 80-85436-38-8.

TRPÁK, Pavel. Křest'anství a odpovědnost na Zemi. Filosofický časopis, 1991, roč. 39, č. 6, s. 992-1000, ISSN 0015-1831.

VAVROUŠEK, Josef. Hledání lidských hodnot slučitelných s trvale udržitelným způsobem života. In PLOS, Jiř́ a Josef VAVROUŠEK (eds.). Lidské hodnoty a společnost v pohybu. Praha: Kruh nezávislé inteligence a Společnost pro trvale udržitelný život, 1994.

\section{Autor}

Vlastimil Hála je vědeckým pracovníkem Filosofického ústavu AV ČR a Centra globálních studií AV ČR a UK. Zabývá se především problematikou dějin filosofie, morální filosofie a etiky, včetně etiky ekologické. Vydal publikace Impulsy Kantovy etiky (Kant - Bolzano Brentano), Možnosti hodnotové etiky a Univerzalismus v etice jako problém. Vedle četných článků především ve Filosofickém časopisu a časopisu Filozofia se rovněž podílel na kolektivních monografí́ch Etika a jej tradícia a Podoby etiky ve spolupráci s D. Smrekovou, Z. Palovičovou a R. Kolářským.

Kontakt: halav@1orien.site.cas.cz 